\title{
STABLE ISOTOPE COMPOSITIONS OF ORGANIC CARBON AND CONTENTS OF ORGANIC CARBON AND NITROGEN OF LACUSTRINE SEDIMENTS FROM SUB-ARID NORTHERN TANZANIA
}

\author{
ANN Muzuka \\ Institute of Marine Sciences,University of Dar es Salaam, \\ P.O. Box 668, Zanzibar, Tanzania.
}

\begin{abstract}
The stable isotope compositions of organic carbon (OC), and contents of $O C$ and nitrogen for four sediment cores recovered from lakes Makat (located in the Ngorongoro Crater), Ndutu and Masek (located in the Serengeti Plains) are used to document sources of organic matter (OM) and climatic changes in sub-arid northern Tanzania during the late Pleistocene-Holocene period. Accelerate mass spectrometer (AMS) ${ }^{14} \mathrm{C}$ ages on total $O M$ for sediments collected from the Ngorongoro Crater Lake indicate that the sedimentation rate is approximately $17 \mathrm{~cm} / \mathrm{ka}$. The $\delta^{13} \mathrm{C}$ values from the $20 \mathrm{~cm}$ long core (short core) show a downcore increase, whereas that of $500 \mathrm{~cm}$ long core (long core), show two peaks enriched in ${ }^{13} \mathrm{C}$ and three peaks depleted in ${ }^{13} \mathrm{C}$. A general downcore increase in the $\delta^{13} C$ values for the short core suggests changes in the relative proportion of $C_{3}$ and $C_{4}$ with $C_{4}$ fraction increasing downcore. Similarly, low and high peaks in the long core suggest changes in the relative proportion of $C_{3}$ and $C_{4}$ with low values having high proportion of $C_{3}$ type of material, probably indicating changes in precipitation and lake levels in the area. Deposition of $O M$ depleted in ${ }^{13} \mathrm{C}$ took place during periods of high precipitation and high lake levels. Although high content of $O C$ and nitrogen in some core sections are associated with elevated $C / N$ ratio values, diagenetic alteration of isotope signature is unlikely to have caused OC isotope enrichment in sections having high contents of $O C$ and nitrogen. The OC isotope record from Lake Ndutu shows a general downcore decrease in $\delta^{13} C$ values and contents of $O C$ and nitrogen. Furthermore, this general trend is punctuated by a period of above normal enrichment in ${ }^{13} \mathrm{C}$, with $\delta^{13} \mathrm{C}$ values being as high as $-6 \%$. A downcore decrease in $\delta^{13} \mathrm{C}$ values and contents of $O C$ and nitrogen could be attributed either to climatic variability or diagenetic effect. Moreover, a peak enriched in ${ }^{13} \mathrm{C}$ probably indicates a period of reduced precipitation, where phytoplankton used dissolved bicarbonate rather than dissolved atmospheric $\mathrm{CO}_{2}$. Lake Mesak record shows two peaks depleted in ${ }^{13} \mathrm{C}$ that are flanked by near constant values of about $20 \%$. These two peaks (depleted in ${ }^{13} \mathrm{C}$ ), which most likely have high proportion of $\mathrm{C}_{3}$ type of $O M$, are associated with low contents of $O C$ and nitrogen. Generally, the contents of OC and nitrogen for this lake are lowest relative to other lakes.
\end{abstract}

\section{INTRODUCTION}

Climate change is partly manifested through variability in precipitation and, over prolonged period of time, changes in vegetation cover. Depending on the level of precipitation, vegetation can change from $\mathrm{C}_{4}$ (mainly grassland) to $\mathrm{C}_{3}$ (mainly forest) dominant type of vegetation. Dense vegetation covers of higher land plants occurs during humid conditions while grasses, which are more tolerant to drought, are the major type of vegetation cover during dry episodes. Plants, which require a lot of water for growth, are generally $\mathrm{C}_{3}$ type and are characterised by stable carbon isotope values that range from -24 to $-31 \%$ o and averaging $-27 \%$ (Deines 1980, Muzuka, 1999, Swap et al. 2004). Similarly, plants that are efficient users of water and adapted to high radiation and temperatures in the growing season (resistant to drought) such as many grasses are generally $\mathrm{C}_{4}$ types and are characterized by stable carbon isotope values that range from -10 to $-16 \%$ and 
Muzuka - Stable isotope compositions of organic carbon ...

averaging -12\% (Deines 1980, Muzuka, 1999, Swap et al. 2004). Because of this, the stable isotopes of $\mathrm{OC}$ for $\mathrm{C}_{3}$ vegetation are generally negatively correlated with rainfall (Swap et al. 2004). Furthermore, as the $\mathrm{C}_{4}$ grasses out-compete $\mathrm{C}_{3}$ plants when atmospheric $\mathrm{CO}_{2}$ levels are low (Cerling et al. 1997, Ehleringer et al. 1997), variations in bulk $\delta^{13} \mathrm{C}$ of the terrestrial biomass in the tropics may reflect changes in atmospheric $\mathrm{CO}_{2}$, temperature, moisture conditions and seasonality of rainfall (Street-Perrott et al. 1997).

In the East African region, several studies have been conducted to document variability in palaeo-precipitation and climate variability using various indicators such as diatoms, mineral magnetic, pollen, stable isotopes and lake levels (Hillaire-Marcel et al. 1986, Hillaire-Marcel and Cassanova, 1987, Johnson et al. 1996 \& 2000, Olago et al. 2000, Stager et al. 1997, Karlén et al. 1999, Gasse, 2000, Talbot and Lærdal 2000, Thompson et al. 2002). Some of these studies have indicated that precipitation at the end of the last glacial period was low, and lake levels were at their lowest level, with shallower lakes like Lake Victoria being completely dry (Johnson et al. 1996, Stager et al. 1997, Talbot and Lærdal 2000). This dry phase was later followed by an increase in precipitation to a maximum level during the early Holocene that culminated at about 5 ka (Hillaire-Marcel and Cassanova 1987, Stager and Mayewski 1997, Stager et al. 1997, Gasse 2000). Although there is a significant amount of information on the climatic condition in the East African region, documentation of climatic changes in northern Tanzania is scanty and available information has been obtained using stromatolites (Hillaire-Marcel et al. 1986, Hillaire-Marcel and Cassanova 1987) and diatoms (Roberts et al. 1993). Furthermore, there is a great potential of using stable isotopes in paleoclimatic studies, but it is evident that only a few studies have used stable isotopes of $\mathrm{OC}$ and nitrogen to document climatic changes in Tanzania (Johnson et al. 2000, Talbot and Laerdal 2000). Thus, the present work documents the Pleistocene-Holocene climatic variability in sub-arid northern Tanzania as preserved in lacustrine sediments of lakes Magat (Ngorongoro Crater), Ndutu and Mesak (Serengeti plains) using the stable isotopes of sedimentary OC and contents of OC and nitrogen. The work also documents changes in the sources of organic matter preserved in these lakes.

\section{Study Area}

The Ngorongoro Crater, which is a large caldera, is located in the northern part of Tanzania at an altitude of more than $2000 \mathrm{~m}$ above sea level. The crater covering a total area of $250 \mathrm{~km}^{2}$ is about $23 \mathrm{~km}$ wide and has an average depth of 600 meters. To the west of the crater lies the famous Serengeti Plains and the Olduvai Gorge, which are relatively at a lower altitude (910-1820 m above sea level). Furthermore, the crater houses thousands of wild animals creating very exciting scenery. 


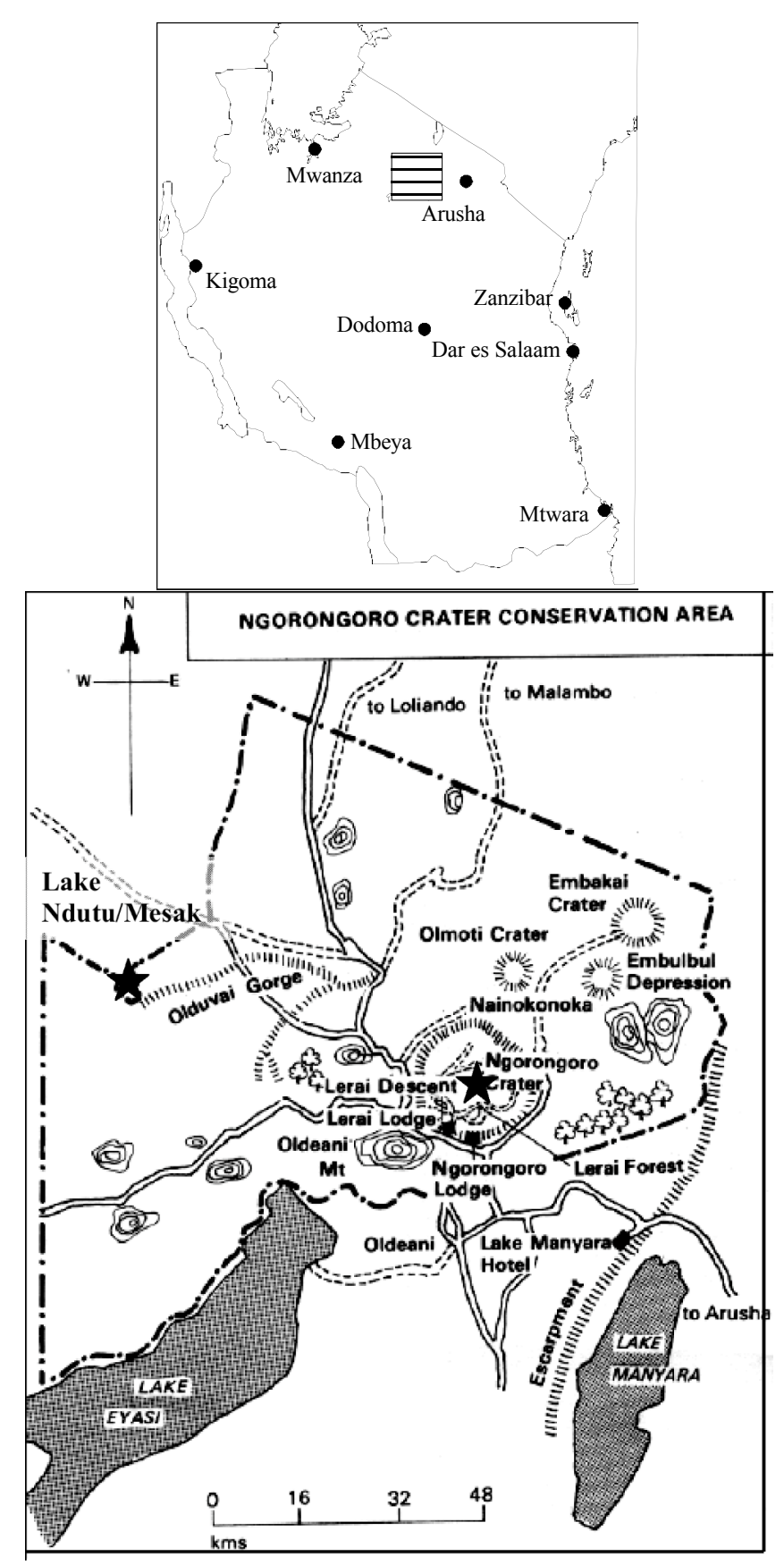

Figure 1: A map showing location of sampling sites of Ngorongoro Crater, Lake Ndutu and Lake Masek. 
Lake Makat or Magadi lies within the Ngorongoro Crater (Fig. 1). The lake, which is alkaline in nature, is shallow and is only 3 meters deep during good rains and during dry season its levels drops dramatically. Sediments deposited in the lake are derived from the flanks of the Ngorongoro Crater.

Lakes Ndutu and Masek, which are about 1 $\mathrm{km}$ apart, are located about $90 \mathrm{~km}$ from the Ngorongoro Crater in the Serengeti Plains and Olduvai Gorge (Fig. 1). The two lakes are alkaline in nature with Lake Ndutu being frequented by flamingos during the rainy season when the lake is full. During the dry season, all of the water of Lake Ndutu evaporates and a thick crust of salt (trona) forms over the lake. Underneath the salt crust is mud; sticky, green, smelly, slimy mud. The nearby Lake Masek is relatively deeper and larger and holds more water so it lasts longer in the dry periods, however, there is no documented water depth.

Like other parts of Tanzania, which are climatically characterized by dry and wet seasons, this northern part of the country receives rain during the months of October through December and March through June. In Tanzania, rainfall is not evenly distributed, with central Tanzania (which include Dodoama and Singida regions) and a large part of Arusha region in the northern Tanzania receiving far less rainfall relative to other parts of the country. Currently, this northern part of Tanzania receives less than $1000 \mathrm{~mm}$ rainfall per year. The 19-year annual rainfall average at Ngorongoro Crater is $900 \mathrm{~mm}$ per year with less rain (about 750 $\mathrm{mm}$ per year) on the crater floor. The sedimentation rates in the crater as well as other lakes located in this region are poorly known.

Geologically, the study area is studded by Neogene volcanic rocks and Quaternary lake beds (Harris 1981). The volcanic rocks are basaltic in nature. In the Olduvai GorgeNdutu area seven major beds namely: Bed I, Bed II, Bed III, Bed IV, the Masek Beds, the
Ndutu Beds, and Baisiusiu Beds have been identified. These beds are rich in skeletal remains of hominids.

\section{MATERIALS AND METHODS}

Sediment cores were obtained from Lake Makat in the Ngorongoro Crater, Lake Ndutu and Lake Masek (Fig. 1) using a flow-through type of corer. Two cores namely MG 0 (20 cm long) and MG 2 (500 $\mathrm{cm}$ long) were recovered in the Ngorongoro Crater Lake. Owing to hard crust at the surface, the upper $100 \mathrm{~cm}$ of MG 2 was not recovered. The sediments for core MG 2 are generally muddy in nature varying in colour from light grey to dark grey or black (Fig. $2)$. However, within the core section there are laminated layer, fine-grained sandy layer and pebbly layer intercalated with mud (Fig. 2).

Cores MES 1 (300 $\mathrm{cm}$ long) and NDU 2 (289 cm long) were retrieved from Lakes Masek and Ndutu respectively, and sediments are muddy in nature with varying colour and particle size (Fig. 2). During sampling, Lake Ndutu was dry and covered by a thick white layer of trona. Wherever possible, cores were sub-sampled every 10 $\mathrm{cm}$, except Core MG 2 which was sampled every $5 \mathrm{~cm}$. Each sample represents a homogenate that is $1 \mathrm{~cm}$ thick.

The stable isotope compositions of $\mathrm{OC}$ and contents of $\mathrm{OC}$ and nitrogen were determined at the GEOTOP, University of Quebec at Montreal and the Department of Geology and Geochemistry, Stockholm University. The stable isotopes were determined using a FINIGAN MAT mass spectrometer, while the contents of $\mathrm{OC}$ and nitrogen were determined using a C-H-N analyser. Sediment samples for the stable isotopes of $\mathrm{OC}$ and contents of $\mathrm{OC}$ were first acidified using $1 \mathrm{M}$ hydrochloric acid, washed of all salts and oven dried at $40^{\circ} \mathrm{C}$. Nitrogen content was determined using unacidfied sediment samples. OC stable isotope data are reported in $\delta$-values relative to the PDB, while the contents of $\mathrm{OC}$ and 
nitrogen are reported in dry weight percentage. Reproducibility of $\mathrm{OC}$ and nitrogen is within . $\pm 2 \%$ and . $\pm 0.1 \%$, respectively. Similarly reproducibility for $\delta^{13} \mathrm{C}$ values is within $\pm 0.1 \%$.

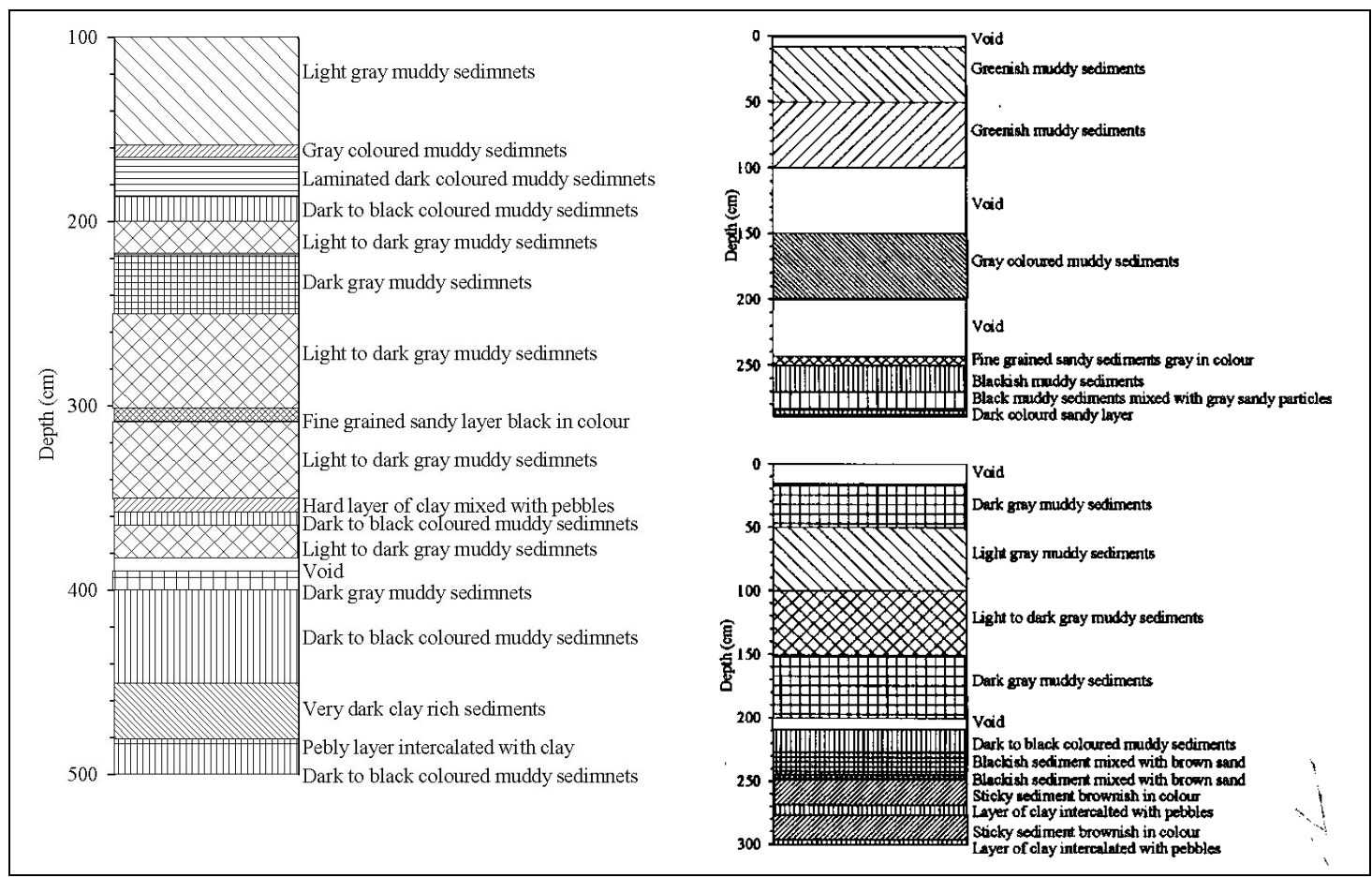

Figure 2: $\quad$ Stratigraphy for cores MG 2 (right), NDU 1 (left top panel) and MES 1 (left bottom panel) collected from Lakes Makat, Ndutu and Masek respectively.

Geochronology of cores MG 0 and MG 2 was established using few ${ }^{14} \mathrm{C}$ data from a nearby site (Core MG 1) located $1 \mathrm{~m}$ apart (Table 1, Fig. 3) under the assumption of equal sediment deposition rate in a radius of $1 \mathrm{~m}$. The geochronology of cores MES 1 and NDU 1 is based on the ${ }^{210} \mathrm{~Pb}$ activity.
Table $1 \quad{ }^{14} \mathbf{C}$ ages determined on total organic matter

\begin{tabular}{ll}
\hline Depth (cm) & ${ }^{14}$ C age \\
\hline 200 & $31335 \pm 880$ \\
300 & $10275 \pm 75$ \\
400 & $25720 \pm 635$ \\
500 & $28320 \pm 655$ \\
\hline
\end{tabular}




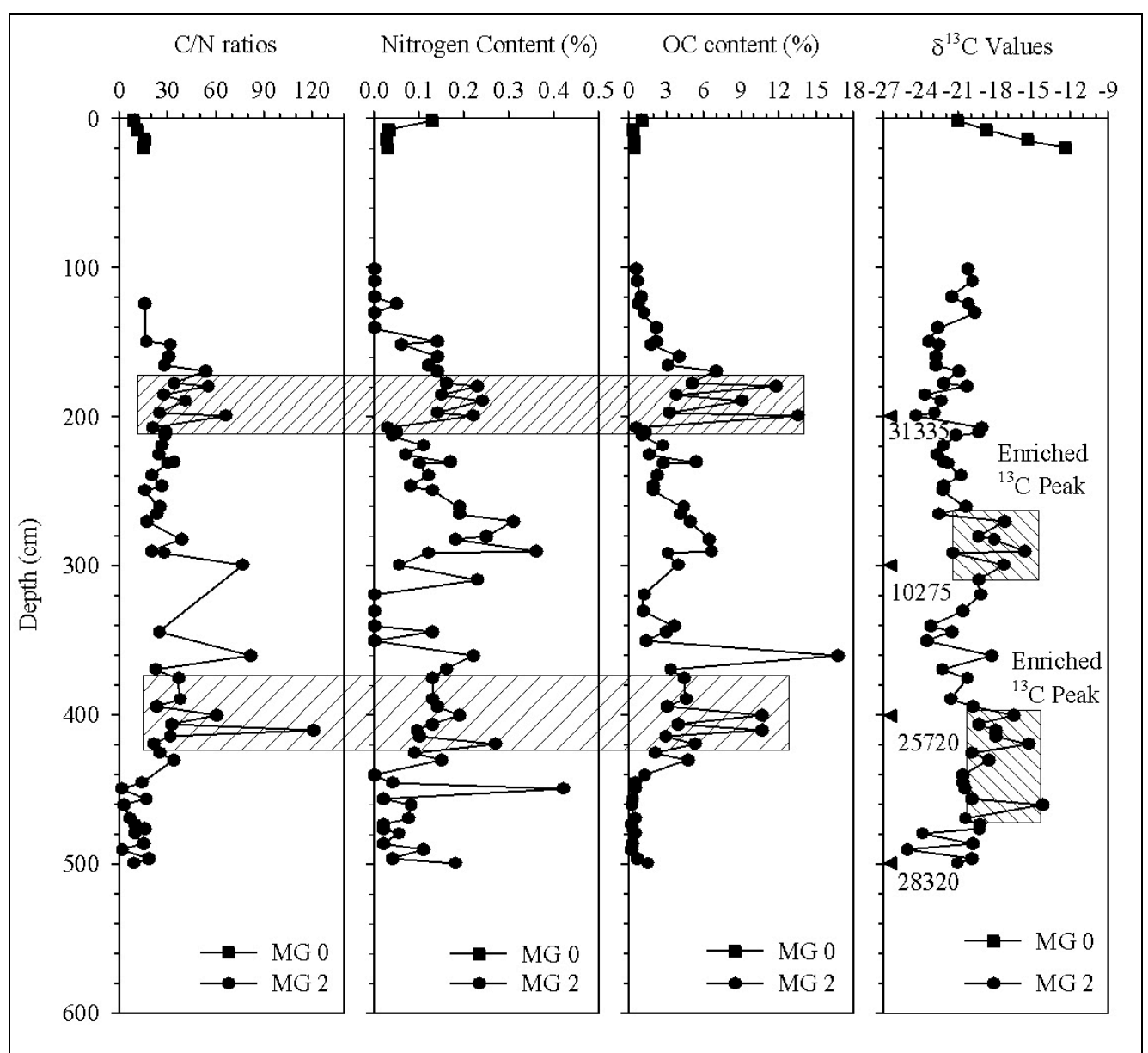

Figure 3: Downcore variation in the stable isotope composition of organic carbon for, and contents of organic carbon and nitrogen for core MG 0 and MG 2 collected from Lake Makat in the Ngorongoro Crater.

\section{RESULTS}

From the ${ }^{14} \mathrm{C}$ data on total $\mathrm{OM}$ for a nearby site $(\sim 1 \mathrm{~m}$ apart; Table 1, Fig. 3$)$, the sedimentation in the Ngorongoro Crater Lake is as high as $11 \mathrm{~cm} / \mathrm{ka} .{ }^{210} \mathrm{~Pb}$ activity for core MES 1 is nearly constant (Fig. 4) indicating that the surface sediments are either older than 100 years or have been homogenised by benthic organisms and wild animals. The activity of ${ }^{210} \mathrm{~Pb}$ for Lake Ndutu decrease exponentially and the estimated recent sedimentation rate (plot of $\mathrm{Ln}{ }^{210} \mathrm{~Pb}$ activity $\mathrm{Vs}$ depth) is about 18.4 $\mathrm{cm} / \mathrm{y}$ (Fig. 4). Downcore trend in the activity of ${ }^{210} \mathrm{~Pb}$ at the two sites (Lake Masek and Ndutu) shows that the supported ${ }^{210} \mathrm{~Pb}$ is around $3 \mathrm{dpm} / \mathrm{g}$ (Fig. 4). 


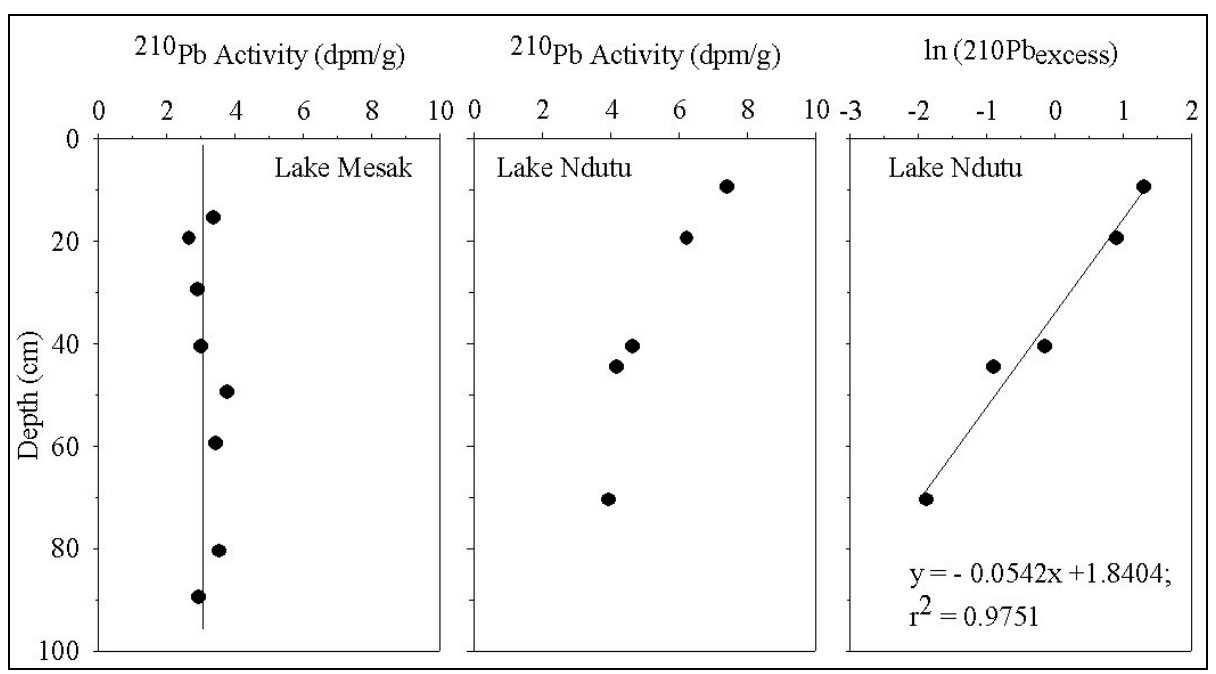

Figure 4: Plots of ${ }^{210} \mathrm{~Pb}$ activity versurs depth for core NDU 1 and MES 1 as well as $1{ }^{210} \mathrm{~Pb}$ activity versus depth for core NDU 1.

\section{Lake Makat}

The $\delta^{13} \mathrm{C}$ values for core MG 0 show a downcore increase, with $\delta$-values ranging from -21 to $-12.5 \%$ and averaging $16.9 \pm 3.8 \%$ (Fig. 2). Similarly, the $\mathrm{C} / \mathrm{N}$ ratio values that range from 8.2 to 14.8 and averaging 11.8 3.0 , increases downcore (Fig. 3). However, the OC content, which ranges from 0.35 to $1.06 \%$ and averaging $0.51 \pm 0.3 \%$, is invariant downcore (Fig. 3). Near constant values are also observable for the nitrogen content that ranges from 0.027 to $0.13 \%$ and averaging $0.05 \pm 0.05$ (Fig. 3). The $\mathrm{C} / \mathrm{N}$ ratio values, which range from 1.1 to 112.2 and averaging $31.2 \pm 25.5$, are generally elevated in cores sections that have high content of organic carbon and nitrogen (Fig. 3).

The $\delta^{13} \mathrm{C}$ values for core MG 2 shows two zones enriched in ${ }^{13} \mathrm{C}$ and 3 zones depleted in ${ }^{13} \mathrm{C}$ when a line is drawn through $-20 \%$ (Fig. 2). Zones enriched in ${ }^{13} \mathrm{C}$ are centred at $300 \mathrm{~cm}$ and $420 \mathrm{~cm}$ (Fig. 2). The $\delta^{13} \mathrm{C}$ values for core MG 2 ranges from -25.1 to $14.3 \%$ and averages $-20.6 \pm 2.2 \%$. The OC and nitrogen contents for core MG 2 are highly variable with low values corresponding to peaks depleted in ${ }^{13} \mathrm{C}$ (Fig. 2). The $\mathrm{OC}$ content ranges from 0.17 to $16.7 \%$ and averages $4.074 .04 \%$. Similarly, the nitrogen content ranges from 0.0 to $0.42 \%$ and averages $0.13 \pm 0.11 \%$.

\section{Lake Ndutu}

The isotope values of OC for core NDU 1 that range from -27.1 to $-7.8 \%$ and averaging $-19.64 \pm 6.4 \%$, shows a general downcore decrease (Fig. 5). This general downcore trend is punctuated with an interval enriched in ${ }^{13} \mathrm{C}$ centred at approximately $180 \mathrm{~cm}$ (Fig. 5). The shift in ${ }^{13} \mathrm{C}$ to higher values is associated with abrupt increase in the contents of OC (Fig. 5 ). The content of $\mathrm{OC}$, which ranges from 0.04 to $3.68 \%$ and averages $0.54 \pm 1.0 \%$, shows downcore decrease in the upper 100 $\mathrm{cm}$, reaching near constant values below it (Fig. 5). Similarly the nitrogen content shows a downcore decrease in the upper 100 $\mathrm{cm}$ followed by near-constant values. Both $\mathrm{OC}$ and nitrogen lack a significant change at about $180 \mathrm{~cm}$ (Fig. 5). The nitrogen content at this site ranges from 0.00 to $0.068 \%$ and averages $0.01 \pm 0.02 \%$. The $\mathrm{C} / \mathrm{N}$ ratios values range from 11.1 to 170.0 and averages 
32.7 \pm 47.0 . The $\mathrm{C} / \mathrm{N}$ values are generally invariant downcore when two high values are excluded and the mean value changes to 14.9 \pm 2.3 . (Fig. 5)

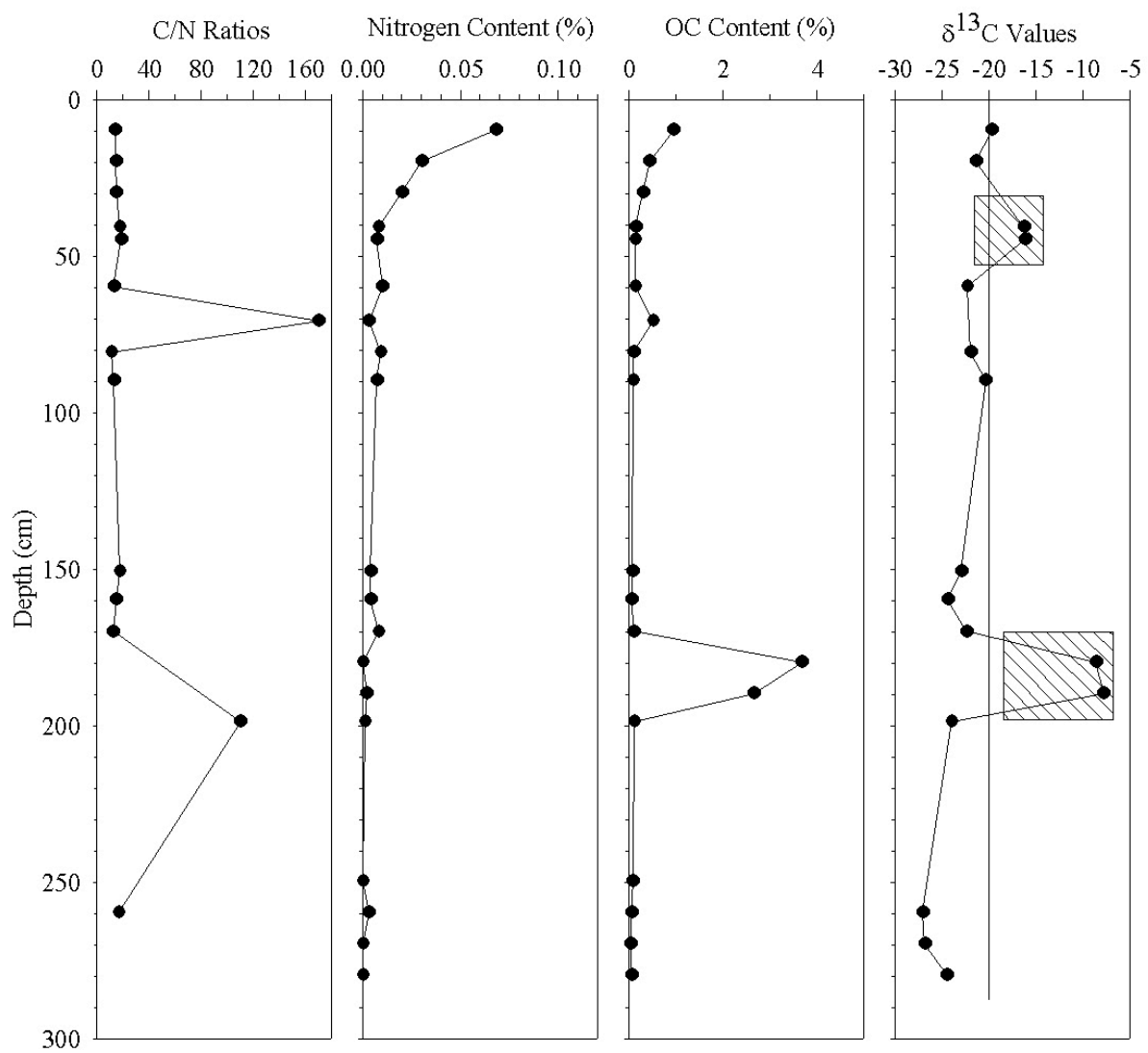

Figure 5: Downcore variation in the stable isotope composition of organic carbon for, and contents of organic carbon and nitrogen for core NDU 1 recovered from Lake Ndutu.

\section{Lake Masek}

The $\delta^{13} \mathrm{C}$ values for core MES 1 show two intervals depleted in ${ }^{13} \mathrm{C}$ at a depths of 120 $\mathrm{cm}$ and $230 \mathrm{~cm}$ that are flanked by near constant values of about $-19 \%$ (Fig. 6). The carbon isotope values at this site range from -25.4 to $-16.4 \%$ and averages $-20.2 \pm 2.4 \%$. Although the contents of OC and nitrogen show high variability, they display a general downcore decrease and they co-vary (Fig.
6). The contents of $\mathrm{OC}$ at this site range from 0.06 to $0.41 \%$ and averages $0.10 \pm 0.07 \%$, while that of nitrogen ranges from 0 to $0.015 \%$ and averaging $0.004 \pm 0.004 \%$. This site has the lowest contents of both $\mathrm{OC}$ and nitrogen relative to other sites. The values $\mathrm{C} / \mathrm{N}$ ratios for this core, which range from 15 to 60 and averaging $25.9 \pm 10.2$, shows a near constant values downcore (Fig. 6). 


\section{Inter-Site Comparison}

Mean isotope values of organic carbon for the three lakes ranges from -20.6 (Makat) to $-19.6 \%$ (Ndutu), when mean isotope value for core MAG 0 is excluded. Owing to lack of good chronology for a core from Lake
Ndutu, the zone enriched in ${ }^{13} \mathrm{C}$ cannot be correlated with any of the Lake Makat zones. Also due to lack of good chronology the Lakes Makat and Masek records cannot be correlated. Lake Masek has the lowest contents of organic carbon and nitrogen.

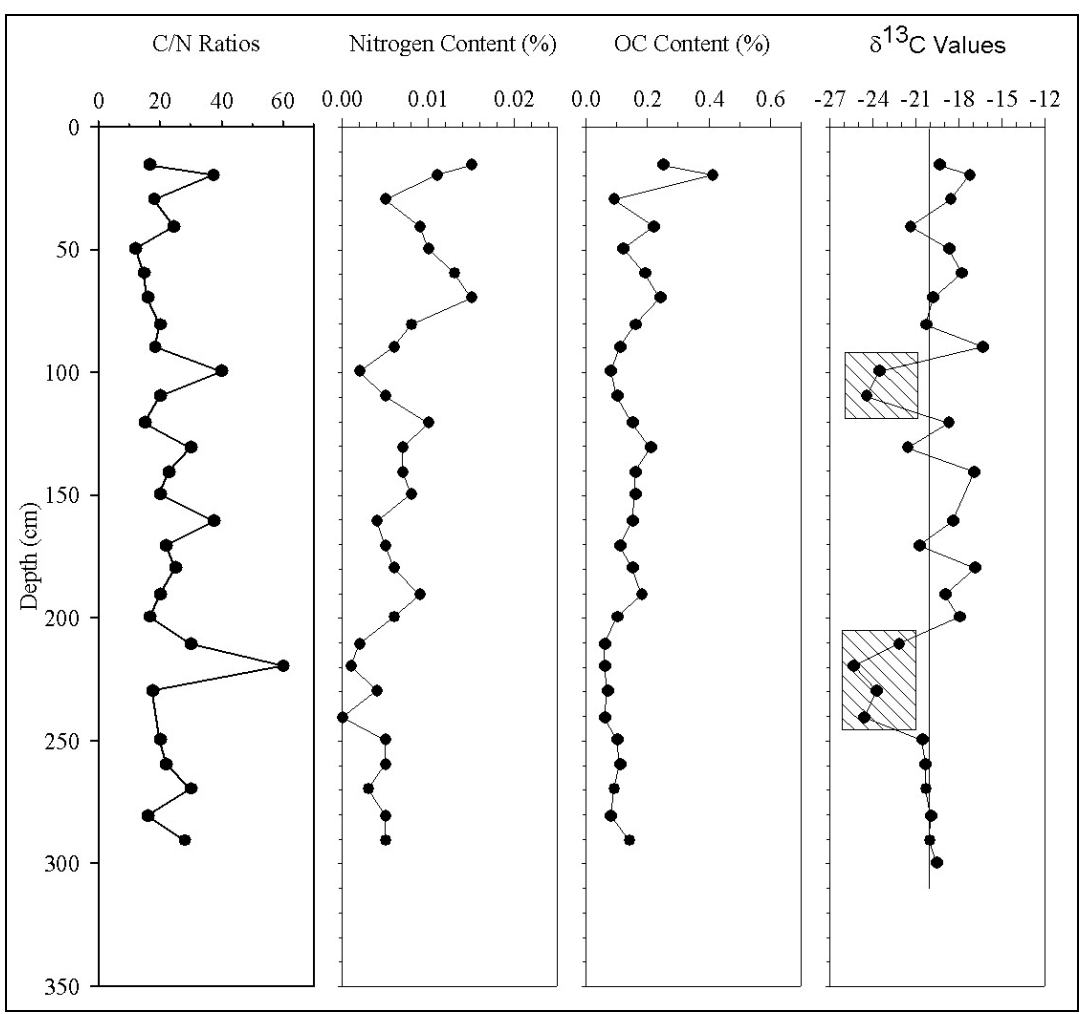

Figure 6: Downcore variation in the stable isotope composition of organic carbon for, and contents of organic carbon and nitrogen for core MES 1 recovered from Lake Masek.

\section{DISCUSSION}

\section{Lake Makat}

As pointed out previously, the stable isotope compositions of OC for core MG 2 display two peaks enriched in ${ }^{13} \mathrm{C}$. Assuming that the two cores (MG 1 and MG 2) collected 1 $\mathrm{m}$ apart have similar chronology, the first ${ }^{13} \mathrm{C}$ enriched peak fall in the time range of uncalibrated radiocarbon dates of 9708 to 12415 , while the second one falls between 21400 and 23200 uncalibrated radiocarbon ages (Fig. 3). The first segments correspond to the Younger Dryas. Available information indicate that in the East African region, the Younger Dryas was associated with low lake levels resulting from aridity (Roberts et al. 1993, Gasse 2000). Similarly the 21-23 ka period, which is considered to be the beginning of the last glacial maximum, was associated with aridity and low lake levels in the East African region (Gasse 2000). Because of aridity during these two-time 
periods where drought resistant $\mathrm{C}_{4}$ plants out-compete $\mathrm{C}_{3}$ type of vegetation, grass was most likely the most dominant type of vegetation. Therefore, the mechanism that led to $\mathrm{OM}$ enrichment in ${ }^{13} \mathrm{C}$ in the two segments of Core $\mathrm{MG} 2$ is preferential preservation of $\mathrm{C}_{4}$ derived plant material.

Another possible mechanism that could have caused enrichment in ${ }^{13} \mathrm{C}$ for the two segments is utilization of bicarbonate by phytoplankton during photosynthesis. Phytoplanktons prefer to utilize dissolved $\mathrm{CO}_{2}$ during synthesis of OM. However, in a situation where demand for $\mathrm{CO}_{2}$ is high particularly during high primary productivity or where waters are highly alkaline, phytoplankton tend to utilize bicarbonate as source of carbon during synthesis of OM (Collister and Hays 1991). When bicarbonate is utilized in the synthesis of OM the resulting organic material will be enriched in ${ }^{13} \mathrm{C}$. Owing to shallowness of the studied lakes and their alkaline nature, this mechanism may contribute to the observed enrichment during Younger Dryas and 21-23 ka periods.

The mean difference in the isotopic compositions between depleted and enriched zones range from 3.2 to $4.9 \%$. The difference in the isotope compositions between the two zones could be attributed to differences in the relative proportion between $\mathrm{C}_{3}$ and $\mathrm{C}_{4}$ type of organic material and utilization of bicarbonate during photosynthesis. Currently areas surrounding the Ngorongoro Crater are semi-arid, and rainfall is less than $1000 \mathrm{~mm}$ per year. The Crater Lake, which is a shallow alkaline lake with $\mathrm{pH}>10$, is a closed lake basin only with water inflow coming from springs and Munge river that originates from the Olmoti crater. A change in these water inflows most likely due to changes in the level of precipitation may easily change the chemistry of the lake. A decrease in inflow from these sources means higher rate of water loss during evaporation, and thus increase in the bicarbonate concentration. Such a process will cause waters to be enriched in ${ }^{13} \mathrm{C}$, and when such waters are utilized by phytoplankton during synthesis of $\mathrm{OM}$ the resulting material will be enriched in ${ }^{13} \mathrm{C}$. Therefore, core sections depleted in ${ }^{13} \mathrm{C}$ could be a result of increase in input of freshwater owing to increase in rainfall in the area and high relative proportion of $\mathrm{C}_{3}$ type of organic material, while core sections enriched in ${ }^{13} \mathrm{C}$ could be a result of high proportion of $\mathrm{C}_{4}$ type of organic material and utilization of bicarbonate during photosynthesis. Because phytoplanktonic materials are rich in nitrogen, the $\mathrm{C} / \mathrm{N}$ ratios are usually less than 10 while that of cellulose rich materials such as land plants have higher $\mathrm{C} / \mathrm{N}$ ratios that are greater than 20 (Meyers 1994, 1997, 2003). A scatter plot of $\mathrm{C} / \mathrm{N}$ ratios versus $\delta^{13} \mathrm{C}$ values, which is a useful plot for easy discrimination of various sources (Meyers 1997, 2003), shows that contribution of phytoplankton to the total organic matter is minimal (Fig. 7).

The contents of organic carbon and nitrogen between 100 and $200 \mathrm{~cm}$ for core MG 2 is high and correspond to relatively low isotope values of $\mathrm{OC}$ and high $\mathrm{C} / \mathrm{N}$ ratios averaging $40.71 \pm 6.8$ (Figs. 3), an indication that the material is enriched in cellulose and is of $\mathrm{C}_{3}$ type of plants. Preferential preservation of $\mathrm{OC}$ and nitrogen during this time period could be attributed to increase in primary productivity in response to increase in nutrient during wetter conditions. Increase in the supply of nutrients could have resulted in high isotope discrimination and thus low isotope values. 

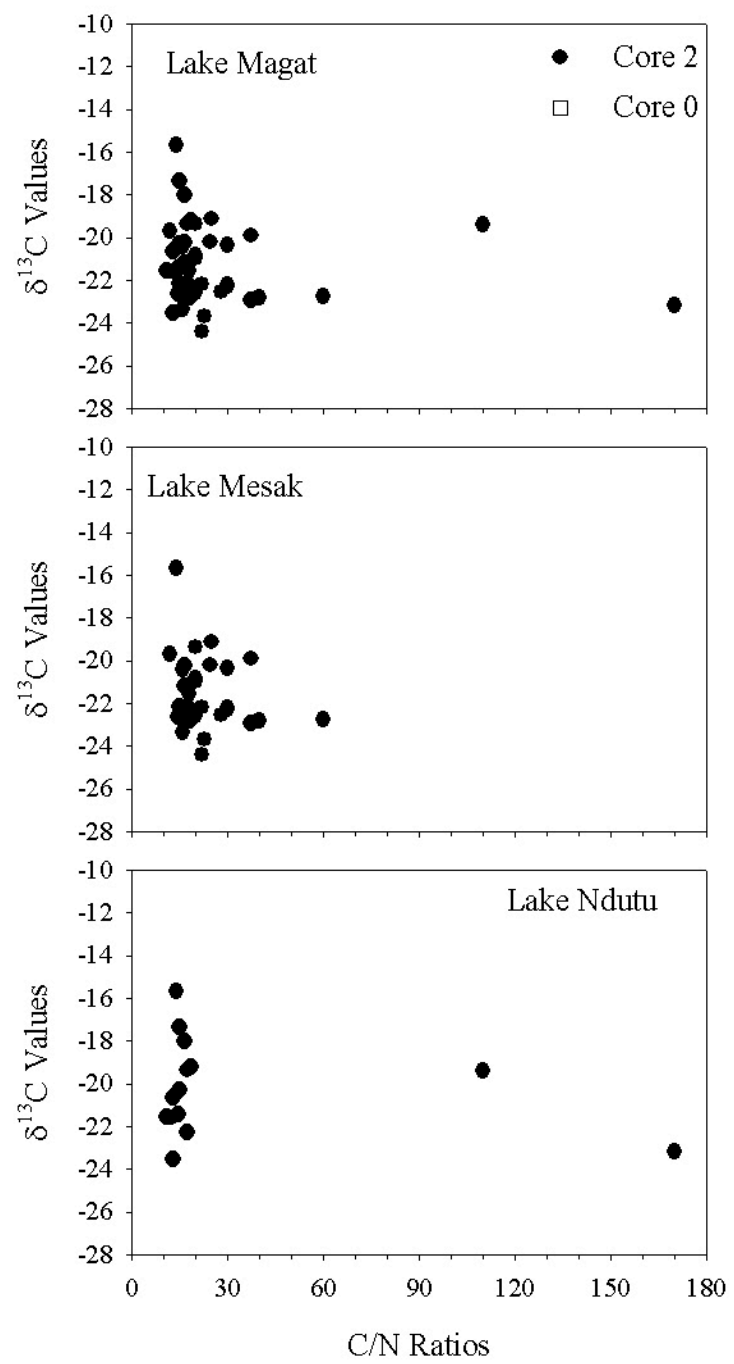

Figure 7: Scatter plots of $\mathrm{C} / \mathrm{N}$ ratios versus $\delta^{13} \mathrm{C}$ values for cores collected from lakes Makat, Ndutu and Masek.

\section{Lake Ndutu}

A downcore decrease in $\delta^{13} \mathrm{C}$ values for the Lake Ndutu sedimentary record could be attributed either to diagenetic alteration of $\mathrm{OM}$ or changes in the relative proportion between $\mathrm{C}_{3}$ and $\mathrm{C}_{4}$ type of organic material. Lower $\mathrm{C} / \mathrm{N}$ ratios that averages $14.9 \pm 2.3$ could be partly a result of diagenetic alteration owing to very low contents of organic carbon and nitrogen, (Fig. 5) Various workers have noted that diagenetic alteration of $\mathrm{OM}$ is associated with either small change or no change in the isotopic compositions of OC (Meyer 1994, Krishnamurthy et al. 1999). However, in areas where organic material has been subjected to high temperatures a significant effect has been noted (Meyers and Simoneit 1999). Because the analysed samples have not been subjected to high temperatures, a change of about 5\%o observed in this study cannot be attributed to diagenetic alteration 
alone. Most likely the results suggest progressive increase in the input of $\mathrm{C}_{4}$ type of OM in recent times. This further suggests that the size of lake Ndutu has progressively declined owing to decrease in precipitation in the area.

\section{Lake Masek}

Core MES 1 is characterized by at least two zones depleted in ${ }^{13} \mathrm{C}$. These zones depleted in ${ }^{13} \mathrm{C}$ can primarily be attributed to decrease in the relative proportion of $\mathrm{C}_{4}$ type of $\mathrm{OM}$ and increase in lake primary productivity. This could have resulted from increase in phytoplanktonic production owing to increase in precipitation and thus lake levels. A scatter plot of $\mathrm{C} / \mathrm{N}$ ratios versus $\delta^{13} \mathrm{C}$ (Fig. 7) shows that the organic material deposited in the lake are rich in cellulose thus derived from $\mathrm{C}_{3}$ and $\mathrm{C}_{4}$ types of land plants.

\section{Inter-Site Correlation}

Although the stable isotope compositions of OC at all three sites (Makat, Ndutu and Masek) have a wide range, they have similar mean value of $-20 \%$. This suggests that mechanisms governing isotope distribution in the three lakes are similar. The stable isotope compositions of East African higher plants have been reported to be about $-28 \%$, while that of grasses have been reported to be $-12 \%$ (Koch et al. 1991; Muzuka, 1999). Therefore, mean $\delta^{13} \mathrm{C}$ values of $-20 \%$ for organic material from this semi-arid area suggest at least $50 \%$ contribution of $\mathrm{C}_{3}$ type of organic material into the sediments of these three lakes. Although the stable isotopic composition of OC for lake phytoplanktonic material ranges from -16 to $-38 \%$ with most of $\delta^{13} \mathrm{C}$ values falling within and below the range of $\delta^{13} \mathrm{C}$ values of $\mathrm{C}_{3}$ plants (Deines 1980, LaZerte and Szalados 1982, Aravena et al. 1992, Meyers 1994, de Giorgio and France 1996, Mitchell et al. 1996, Tenzer et al. 1997), a plot of C/N ratio versus $\delta^{13} \mathrm{C}$ values (Fig. 7) show that phtytoplankton contribution is minimum. However, because of lower contents of OC and nitrogen particularly for cores collected from Lakes Ndutu and Masek, which can potentially be diagenetically altered and adsorpted to clay particles leading to lower $\mathrm{C} / \mathrm{N}$ ratios (Muller, 1977), this parameter alone can not exclude the possibility of the presence of phytoplanktonic material.

The OC and nitrogen content for Lake Makat in the Ngorongoro Crater is higher compared to the other two lakes (Ndutu and Masek) an indication of preferential preservation of $\mathrm{OC}$ and nitrogen in Lake Makat. Poor preservation of $\mathrm{OM}$ in Lake Ndutu and Masek could be attributed to frequent exposure of sediments to high concentration of oxygen when the lakes dry up. Furthermore, it could also be a result of low primary productivity and small input of OM from the catchment's basin.

\section{CONCLUSION}

The stable isotope values for three lakes (Lake Makat, Ndutu and Masek) located in semi-arid northern Tanzania averages -20\%o suggesting that $\mathrm{C}_{4}$ plants contribute at least $50 \%$ to the total OC preserved in the lake. The ${ }^{13} \mathrm{C}$ record shows that Lake Makat experienced input of organic material enriched in ${ }^{13} \mathrm{C}$ during the Younger Dryas and between 21 and 23 ka periods that can be attributed to deposition of high proportion of $\mathrm{C}_{4}$ type of organic material and utilization of bicarbonate by phytoplankton. The stable isotopes of OC show major variations in the composition of $\mathrm{C}_{3}$ derived $\mathrm{OM}$ material deposited in the three lakes. Although inter-core correlation is not possible owing to poor chronology, the isotope data may be interpreted to show that enriched sections were deposited during dry periods and vice versa.

Contents of OC and nitrogen for cores MES 1 and NDU 1 are generally low and have been significantly affected by diagenetic processes. However, the stable isotope signatures seems to have undergone little alteration. 


\section{ACKNOWLEDGEMENTS}

I am grateful to the management of the Ngorongoro Conservation Area Authority (NCAA) for the permission to undertake coring activity within the Conservation Area. Equipment and cooperation from Prof. Wibjön Karlén and Marianne Lagerklint of the Stockholm University and Dr. Nyandwi of the Institute of Marine Sciences is highly acknowledged. Laboratory assistance by GEOTOP-UQAM and the Department of Geology and Geochemistry, Stockholm University is highly acknowledged. This work was made possible by Research grant from the International Atomic Energy Agency (IAEA) contract No. 9715/R1.

\section{REFERENCES}

Aravena R, Warner B, MacDonald GL and Hanf K 1992 Carbon isotope compositions of lake sedimnts in relation to lake productivity and radiocarbon dating. Quaternary Research 37: 333345.

Cerling TE, Harris JM, MacFadden BJ, Leakey MG, Quade J, Eisenmann V and Ehleringer JR 1997 Global change through the Miocene/Pliocene boundary. Nature 389: 153-158.

Collister JW and Hays JM 1991 A preliminary study of the carbon and nitrogen isotope biogeochemistry of lacustrine sedimentary rocks from the Green River Formation, Wyoming, Utah and Colorado. United States Geological Survey Bulletin 1973-A-G: C1-C16.

de Giorgio PA and France R L 1996 Ecosystem-specific patterns in the relationship between zooplakton and POM or microplankton $\delta^{13} \mathrm{C}$. Limnology and Oceanography 41: 359-365.

Deines ET 1980 The isotopic composition of reduced organic carbon, in P. Fritz, and J.Ch. Fontes (eds.) Handbook of Environmental Isotope Geochemistry, Vol. 1A. Elsevier, New York, pp. 329406.

Ehleringer JR, Cerling TE and Helliker B $1997 \mathrm{C}_{4}$ photosynthesis, atmospheric
$\mathrm{CO}_{2}$, and climate. Oecologia 112: 285299.

Gasse F 2000 Hydrological changes in the African tropics since the last glacial maximum. Quaternary Science Review 19: $189-211$.

Harris JF 1981 Summary of the Geology of Tanganyika Part IV: Economic Geology. Government Printer, Dar es Salaam, $143 \mathrm{pp}$.

Hillaire-Marcel C and Cassanova J 1987 Isotopic hydrology and paleohydrology of the Magadi (Kenya)-Natron (Tanzania) basin during the late Quaternary. Palaeogeography, Palaeoclimatology, Palaeoecology 58: 155-181.

Hillaire-Marcel C, Carro O and Casanova J 1986. ${ }^{14} \mathrm{C}$ and $\mathrm{Th} / \mathrm{U}$ dating of Pleistocen and Holocene stromatolites from East African paleolakes. Quaternary Research 25: 312-329.

Johnson TC, Kelts K and Odada E 2000. The Holocene history of Lake Victoria. Ambio 29: 2-11.

Johnson TC, Scholz CA, Talbot MR, Kelts K, Ricketts RD, Ngobi G, Beuning K, Ssemmanda I and McGill 1996 Late Pleistocene desiccation of Lake Victroria and rapid evolution of Cichlid Fishes. Science 273: 1091-1093.

Karlén W, Fastook JL, Holmgren K, Malmström M, Mathews JA, Odada E, Risberg J, Rodsqvist G, Sandgren P, Shemesh A and Westerberg L-O 1999 Glacier fluctuations on mount Kenya since $\sim 6000$ Cal. Years BP: Implications for Holocene climatic change in Africa. Ambio 28: 409-417.

Koch PL, Behrensmeyer AK and Fogel M 1991 The isotopic ecology of plants and animals in Amboseli National Park, Kenya. Geophysical Laboratory, Carnegie Institution Year Book 1990/91: 163-171.

Krishnamurthy RV Syrup K and Long A 1999 Is selective preservation of nitrogenous organic matter reflected in the $\delta^{13} \mathrm{C}$ signal of lacustrine sediments? Chemical Geology 158: 165-172. 
Muzuka - Stable isotope compositions of organic carbon ...

LaZerte BD and Szalados E 1982 Stable isotope ratio of submerged freshwater macrophytes. Limnology and Oceanography 27: 413-418.

Meyers PA and Simoneit BRT 1999 Effects of extreme heating on the elemental and isotopic compositions of an Upper Cretaceous coal. Organic Geochemistry 30: 299-305.

Meyers PA 1994 Preservation of elemental and isotopic source identification of sedimentary organic matter. Chemical Geology 114: 289-302.

Meyers PA 1997 Organic Geochemical proxies of paleceanographic, paleolimnologic, and paleoclimatic processes. Organic Geochemistry 27: 213-250.

Meyers PA 2003. Application of organic geochemistry to paleolimnological reconstructions: a summary of examples from the Laurentian Great Lakes. Organic Geochemistry 34: 261-289.

Mitchell MJ, Mills EL, Idrisi N and Michener R 1996 Stable isotopes of nitrogen and carbon in an aquatic food web recently invaded by Dreissena polymorpha (Pallas). Canadian Journal of Fisheries and Aquatic Sciences 53: 1445-1450.

Müller PJ 1977. C/N ratios in Pacific deep-sea sediments: Effect of inorganic ammonium and organic nitrogen compounds sorbed by clays. Geochimica et Cosmochimica Acta 41: 765-776.

Muzuka ANN 1999 Isotopic compositions of tropical East African flora and their potential as source indicators of organic matter in coastal marine sediments. Journal of African Earth Sciences 28: 757-766.

Olago DO, Steet-Perrott FA, Perrott RA, Ivanovich M, Harkness DD and Odada EO 2000 Long-term temporal characteristics of paleomonsoon dynamics in equatorial Africa. Global and Planentary Change 26: 159-171.
Roberts N, Taleb M, Barker P, Damnatl B, Icole M and Williamson D 1993 Timing of the Younger Dryas event in East Africa from lake-level changes. Nature 366: 146-148.

Stager JC and Mayewski PA 1997 Abruptearly to Mid-Holocene climatic transition regiasted at the Equator and the Poles. Science 276: 1834-1836.

Stager JC, Cumming,B and Meeker L 1997 A high resolution $11,400-Y r$ diatom record from Lake Victoria, East Africa. Quaternary Research 47: 81-89.

Street-Perrott FA, Huang Y, Perrott RA, Eglinton G, Barker P, Khelifa, LB, Harkness DD and Olago DO 1997 Impact of lower atmospheric carbon dioxide on tropical mountain ecosystems. Science 278: 1422-1426.

Swap RJ, Aranibar JN, Dowty PR, Gilhooly $\mathrm{W}$ and Macko SA 2004 Natural abundance of ${ }^{13} \mathrm{C}$ and ${ }^{15} \mathrm{~N}$ in $\mathrm{C}_{3}$ and $\mathrm{C}_{4}$ vegetation of southern Africa:patterns and implications. Global Change Biology 10: 350-358

Talbot MR and Lærdal T 2000 The late Pleistocene-Holocene palaeolimnology of Lake Victoria, East Africa, based upon elemental and isotopic analyses of sedimentary organic matter. Journal of Paleolimnology 23: 141-164.

Tenzer GE, Meyers PA and Knoop P 1997 Sources and distribution of organic and carbonate carbon in surface sediments of Pyramid Lake, Nevada. Journal of Sedimentary Research 67: 884-890.

Thompson LG, Mosley-Thompson E, Davis ME, Henderson KA, Brecher $\mathrm{HH}$, Zagorodnov VS, Mashiotta TA, Lin P-N, Mikhalenko VN, Hardy DR and Beer J 2002 Kilimanjaro Ice Core Records: Evidence of Holocene Climate Change in Tropical Africa. Science 298: 589593. 